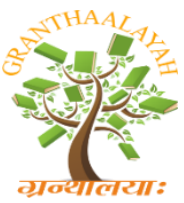

\author{
INTERNATIONAL JOURNAL OF RESEARCH - \\ GRANTHAALAYAH \\ A knowledge Repository
}

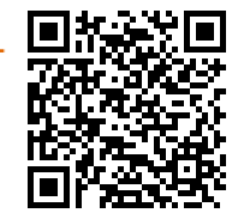

Science

\title{
MEASUREMENT OF TRENDS OF SOME INFLUENTIAL VARIABLES: A COMPARISON BETWEEN BRAC BANK LTD. AND ISLAMI BANK BANGLADESH LTD.
}

\author{
Professor Dr. Md. Abu Sina ${ }^{1}$, Dr. Md. Abdus Sabur ${ }^{2}$ \\ ${ }^{1}$ Department of Accounting \& Information Systems, Islamic University, Kushtia, Bangladesh \\ 2 Associate Professor, Department of Accounting \& Information Systems, Islamic University, \\ Kushtia, Bangladesh
}

\begin{abstract}
Banking sector is a fundamental element of a financial system of a country. Bangladesh is a developing country and its financial system is good and upward trend oriented. Islami Bank Bangladesh Limited (IBBL) and BRAC Bank Limited (BBL) are the two prospective banks in Bangladesh. The paper attempts to measure trends of some influential variables. Through KaiserMeyer-Olkin (KMO) and Bartlett's test of Sphericity five influential variables are identified like net profit, investment/loans and advances, fixed assets, other assets and cash. All the variables show better position in IBBL than BBL. The researchers also have identified some problems in IBBL and BBL and recommended some suggestions for overcoming the problems.
\end{abstract}

Keywords: Trend; Influential Variables; BRAC Bank Ltd; Islami Bank Bangladesh Ltd.

JEL Code: G21.

Cite This Article: Professor Dr. Md. Abu Sina, and Dr. Md. Abdus Sabur. (2017). "MEASUREMENT OF TRENDS OF SOME INFLUENTIAL VARIABLES: A COMPARISON BETWEEN BRAC BANK LTD. AND ISLAMI BANK BANGLADESH LTD." International Journal of Research - Granthaalayah, 5(7), 530-540. https://doi.org/10.29121/granthaalayah.v5.i7.2017.2161.

\section{Introduction}

Islami Bank Bangladesh Limited (IBBL) and BRAC Bank Limited (BBL) are the two growing banks in Bangladesh. A short snapshot of the two banks is stated below:

\begin{tabular}{|l|l|}
\hline IBBL & BBL \\
\hline History & History \\
Islami Bank Bangladesh Limited is a sharia & $\begin{array}{l}\text { BRAC Bank was founded on 4 July 2001 to reach the large number } \\
\text { compliant bank in Bangladesh which started } \\
\text { of unbanked people which were not covered by traditional bank. The } \\
\text { operations on 30 March 1983. It is a public } \\
\text { main concept of the bank was to facilitate Small and Medium } \\
\text { limited company registered under the Companies } \\
\text { Act of 1913. IBBL is a joint venture of the }\end{array}$ \\
\hline
\end{tabular}


government of Bangladesh, 22 businessmen of Bangladesh, Islamic Development Bank, and investment firms and banks from Muslim Middle Eastern countries.

\section{Mission}

To establish Islamic Banking through the introduction of a welfare-oriented banking system, to achieve balanced growth and equitable development through diversified investment operations particularly in the priority sectors and less developed areas of the country. By this way, IBBL always tries to ensure every day quality and complied services to its valued clients.

\section{Core Values}

i) Trust in Almighty Allah.

ii) Strict observance of Islamic Shari'ah.

iii) Highest standard of Honesty, Integrity \& Morale through ensuring Proper Delegation, Transparency \& Accountability.

iv) Environmental Consciousness.

v) Adoption of updated Technology.

vi) Ensuring every day customized quality service.

\section{Mission}

Building a profitable and socially responsible financial institution focused on market and business with growth potential, thereby assisting BRAC and stakeholders build a "just, enlightened, healthy, democratic and poverty-free Bangladesh”.
Core Values

i) Sustained growth in 'Small \& Medium Enterprise' sector

ii) Continuous low-cost deposit growth with controlled growth in Retail Assets

iii) Corporate Assets to be funded through self-liability mobilization. Growth in Assets through Syndications and Investment in faster growing sectors

iv) Continuous endeavor to increase non-funded income

v) Keep our Debt Charges at $2 \%$ to maintain a steady profitable growth

vi) Achieve efficient synergies between the bank's branches. SME unit offices and BRAC field offices for delivery of Remittance and Bank's other products and services

vii) Manage various lines of business in a fully controlled environment with no compromise on service quality

viii) Keep a diverse, far flung team fully motivated and driven towards materializing the Bank's vision into reality

Source: IBBL, en.banglapedia.org and BBL, en.banglapedia.org.

Research questions are i) what is the position of the two banks? ii) What are the differences between net profit of the banks and other variables? iii) What are the trends showed by the banks performance regarding the selected variables?

This paper is an attempt to answer the above mentioned research questions.

\section{Objective of the Study}

1) To explore the status of IBBL and BBL;

2) To find out the position of selected variables of the selected banks;

3) To measure the trends of the selected variables of the banks under study; and

4) To provide suggestions for the betterment of the banks.

\section{Research Methodology}

The study is done on the basis of secondary sources. Primary data are collected only for identifying problems and recommendations. Face to face interview i.e., of the bank employees are taken in this regard. Study period is from 2005 to 201511 years. Out of eight Islamic banks and 32 conventional banks in Bangladesh two banks i.e., one from conventional sector and one from Islamic sector have been chosen by the researchers purposively. Kaiser-Meyer-Olkin 
(KMO) and Bartlett's test of Sphericity is used to determine influential variables. Trend analysis is done on the five influential variables of the two banks. Graphical presentations are made to justify the position of the banks under study.

\section{Justification of the Selected Variables}

To measure the trends of the variables, at first justification of the selection of variables are done through Kaiser-Meyer-Olkin (KMO) and Bartlett's test of Sphericity as under:

Table 1: KMO and Bartlett's Test of Variables for the Selected Banks

\begin{tabular}{|c|c|c|}
\hline \multicolumn{3}{|c|}{ KMO and Bartlett's Test } \\
\hline \multirow{2}{*}{ Kaiser-Meyer-Olkin Measure of Sampling Adequacy. } & 0.799 \\
\hline \multirow{3}{*}{ Bartlett's Test of Sphericity } & Approx. Chi-Square & 503.892 \\
\cline { 2 - 3 } & df & 45 \\
\cline { 2 - 3 } & Sig. & 0.000 \\
\hline
\end{tabular}

Source: Calculated from Principal component analysis.

The results of Kaiser-Meyer-Olkin (KMO) and Bartlett's test of Sphericity for the selected banks has been shown in Table No.1. Bartlett's test of sphericity reveals that the approximate chisquare values of variables for selected banks is 503.892 with 45 degrees of freedom at 0.00 levels of significance. KMO measures the adequacy of samples to examine the appropriateness of factor analysis where values between 0.5-1.0 indicate factor analysis is appropriate. Values below 0.5 imply that factor analysis may not be appropriate. The KMO's values is 0.799 indicating the factor analysis is appropriate for the measurement.

Table 2: Total Variance Explained

\begin{tabular}{|c|c|c|c|c|c|c|c|c|c|}
\hline \multirow[b]{2}{*}{ Component } & \multicolumn{3}{|c|}{ Initial Eigen Values } & \multicolumn{3}{|c|}{$\begin{array}{l}\text { Extraction Sums of } \text { Squared } \\
\text { Loadings }\end{array}$} & \multicolumn{3}{|c|}{$\begin{array}{llll}\begin{array}{l}\text { Rotation Sums of } \\
\text { Loadings }\end{array} & & \text { Squared } \\
\end{array}$} \\
\hline & Total & $\begin{array}{l}\% \text { of } \\
\text { Variance }\end{array}$ & $\begin{array}{l}\text { Cumulative } \\
\%\end{array}$ & Total & $\begin{array}{l}\% \text { of } \\
\text { Variance }\end{array}$ & $\begin{array}{l}\text { Cumulative } \\
\%\end{array}$ & Total & $\begin{array}{l}\% \text { of } \\
\text { Variance }\end{array}$ & $\begin{array}{l}\text { Cumulative } \\
\%\end{array}$ \\
\hline 1 & 7.851 & 78.513 & 78.513 & 7.851 & 78.513 & 78.513 & 4.362 & 43.615 & 43.62 \\
\hline 2 & 1.127 & 11.267 & 89.780 & 1.127 & 11.267 & 89.780 & 3.894 & 38.939 & 82.55 \\
\hline 3 & .688 & 6.878 & 96.659 & .688 & 6.878 & 96.659 & 1.154 & 11.536 & 94.09 \\
\hline 4 & .161 & 1.606 & 98.264 & .161 & 1.606 & 98.264 & .317 & 3.171 & 97.26 \\
\hline 5 & .106 & 1.061 & 99.326 & .106 & 1.061 & 99.326 & .206 & 2.065 & 99.33 \\
\hline 6 & .042 & .422 & 99.747 & & & & & & \\
\hline 7 & .021 & .206 & 99.953 & & & & & & \\
\hline 8 & .003 & .030 & 99.983 & & & & & & \\
\hline 9 & .001 & .015 & 99.997 & & & & & & \\
\hline 10 & .000 & .003 & 100.000 & & & & & & \\
\hline
\end{tabular}

Extraction method: Principal component analysis

As per the Table No.2, It is find that the total variance explain is 99.33 percent for results where five factors have been extracted by the principal component analysis. It indicates the selected variables of banks variables depend on five major factors. Hence we can reduce the number of variables included in the study within components (factors) as under: 
Table 3: Rotated Component Matrix

\begin{tabular}{|c|c|c|c|c|c|}
\hline \multirow[b]{2}{*}{ Variables } & \multicolumn{5}{|c|}{ Component } \\
\hline & 1 & 2 & 3 & 4 & 5 \\
\hline Nproft & .932 & & & & \\
\hline Rtern & .907 & .381 & & & \\
\hline Cash & .777 & .471 & & & .385 \\
\hline Invest & .644 & .643 & & & \\
\hline Gproft & & .966 & & & \\
\hline Tasst & .622 & .754 & & & \\
\hline Depst & .622 & .746 & & & \\
\hline Fast & .605 & .705 & & .332 & \\
\hline Teqty & .682 & .694 & & & \\
\hline Oasst & & & .996 & & \\
\hline
\end{tabular}

Extraction Method: Principal Component Analysis. Rotation Method: Varimax with Kaiser Normalization. Rotation converged in 5 iterations.

Here, Nprofit $=$ Net Profit, Rturn $=$ Return, Invest $=$ Investment $/$ Loans, Gprofit $=$ Gross Profit, Tasst $=$ Total Assets, Depst $=$ Deposit, Fast $=$ Fixed Assets, Tseqty $=$ Total Equity and Oasset $=$ Other Assets.

To elaborate the fact that different variables are related to different dimensions (factors), the Table No. 3 displays the rotated component matrix. In this table, how rotation achieves simplicity of data reduction and enhances interpretability of the function of the influential variables of selected banks is found. It is also found that the variable net profit (nproft), investment/loans(invest), other asset (oasset), fixed asset (fast) and cash for the component $1,2,3,4$, and 5 respectively where the highest loading is happened. Thus the influential variables are estimated as net profit, investment, other asset, fixed assets and cash for measurement of the selected banks. The following interpretations have done with these variables.

\section{Analysis and Findings}

Analyses of four influential variables are stated below:

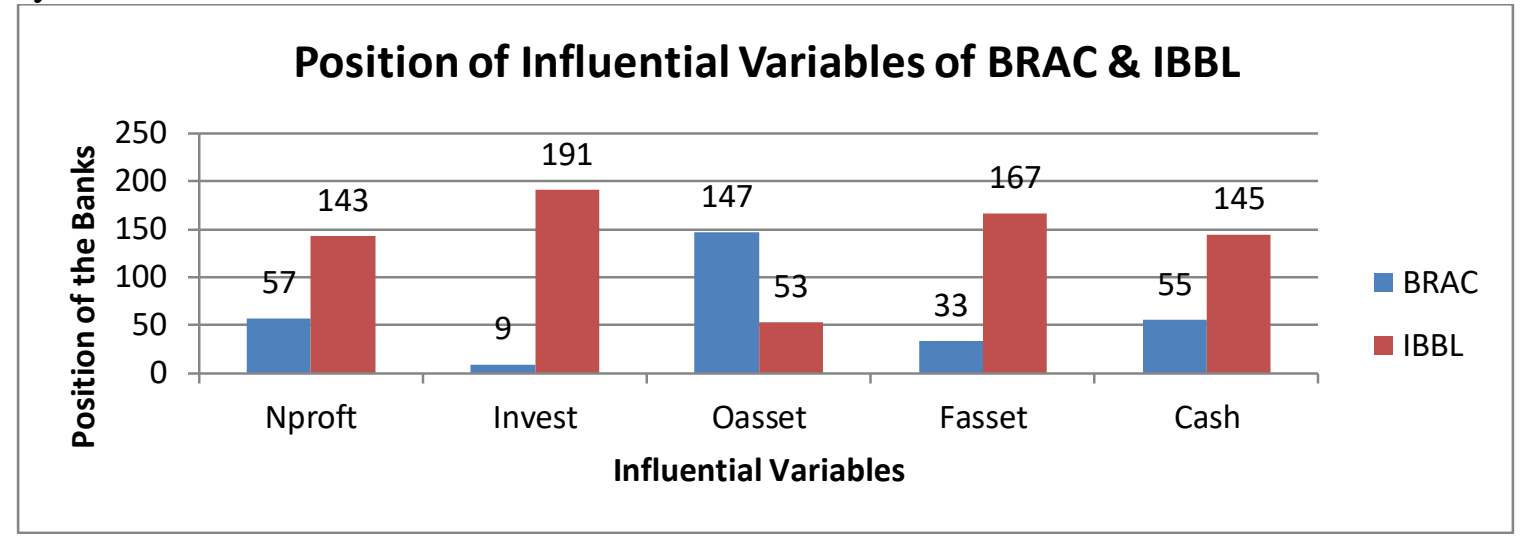

Chart 1:

Source: Compiled from the monetary values of the selected variables.

Above table shows that all the variables of IBBL are larger than those of BBL. 
Table 4:

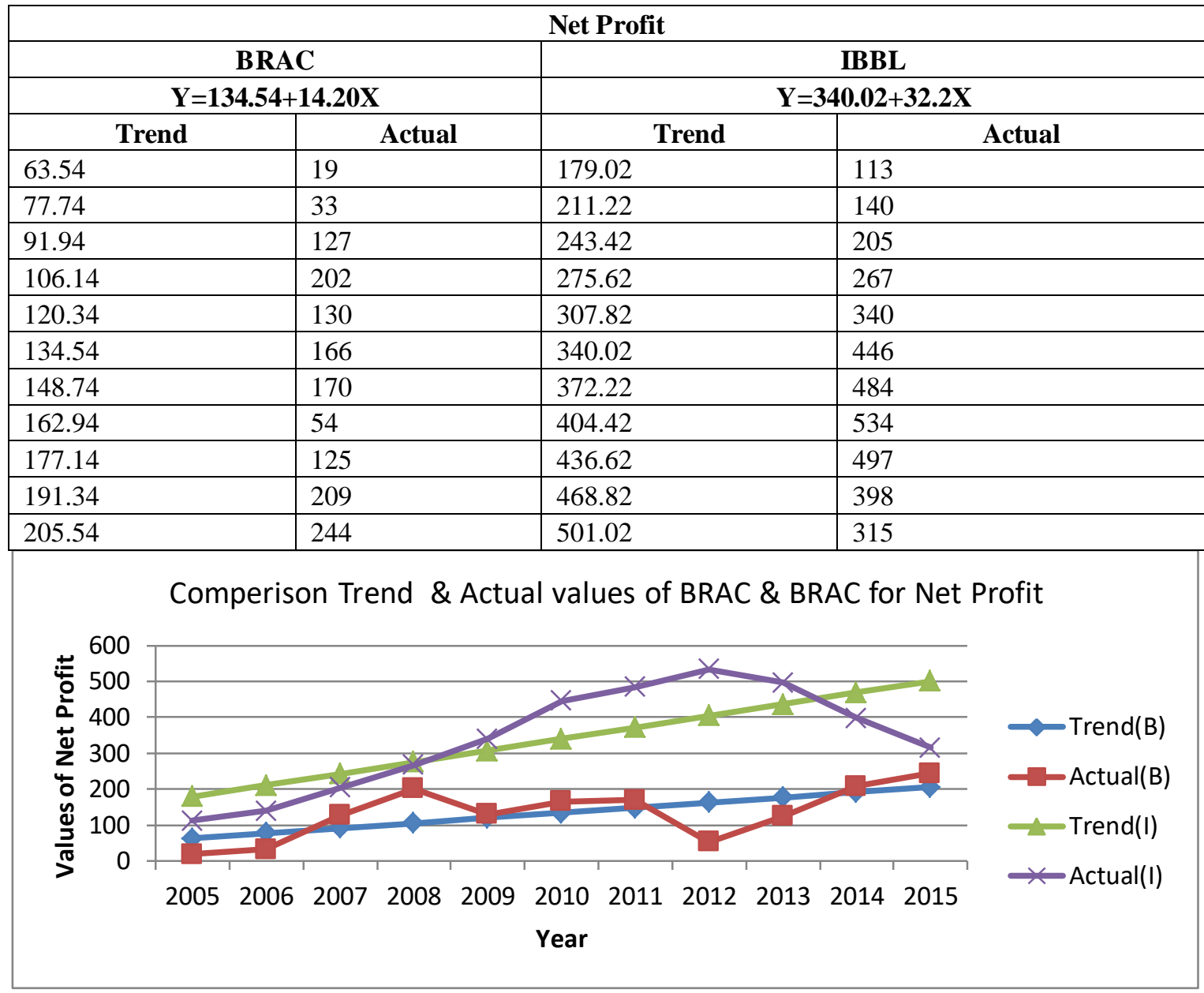

Source: Table No. 4.

Chart 2:

Table \# 4 and Chart \# 2 show higher trend of IBBL than that of BBL regarding net profit.

Table 5:

\begin{tabular}{|c|c|c|c|}
\hline \multicolumn{4}{|c|}{ Investment } \\
\hline & BRAC & \multirow{2}{*}{\multicolumn{2}{|c|}{$\begin{array}{c}\text { IBBL } \\
Y=29551.3+4509.6 \mathrm{X}\end{array}$}} \\
\hline \multicolumn{2}{|c|}{$Y=1335.94+232.35 X$} & & \\
\hline Trend & Actual & Trend & Actual \\
\hline 174.19 & 216.38 & 7003.3 & 9717.83 \\
\hline 406.54 & 376.8 & 11512.9 & 11713.28 \\
\hline 638.89 & 499.69 & 16022.5 & 16528.64 \\
\hline 871.24 & 824.54 & 20532.1 & 18758.65 \\
\hline 1103.59 & 1037.53 & 25041.7 & 22575.23 \\
\hline 1335.94 & 1285.59 & 29551.3 & 27549.39 \\
\hline 1568.29 & 1419.88 & 34060.9 & 32277.29 \\
\hline 1800.64 & 2537.25 & 38570.5 & 39993.08 \\
\hline 2032.99 & 2129.86 & 43080.1 & 47401.59 \\
\hline 2265.34 & 2389.9 & 47589.7 & 46038.54 \\
\hline 2497.69 & 1977.9 & 52099.3 & 52510.45 \\
\hline
\end{tabular}




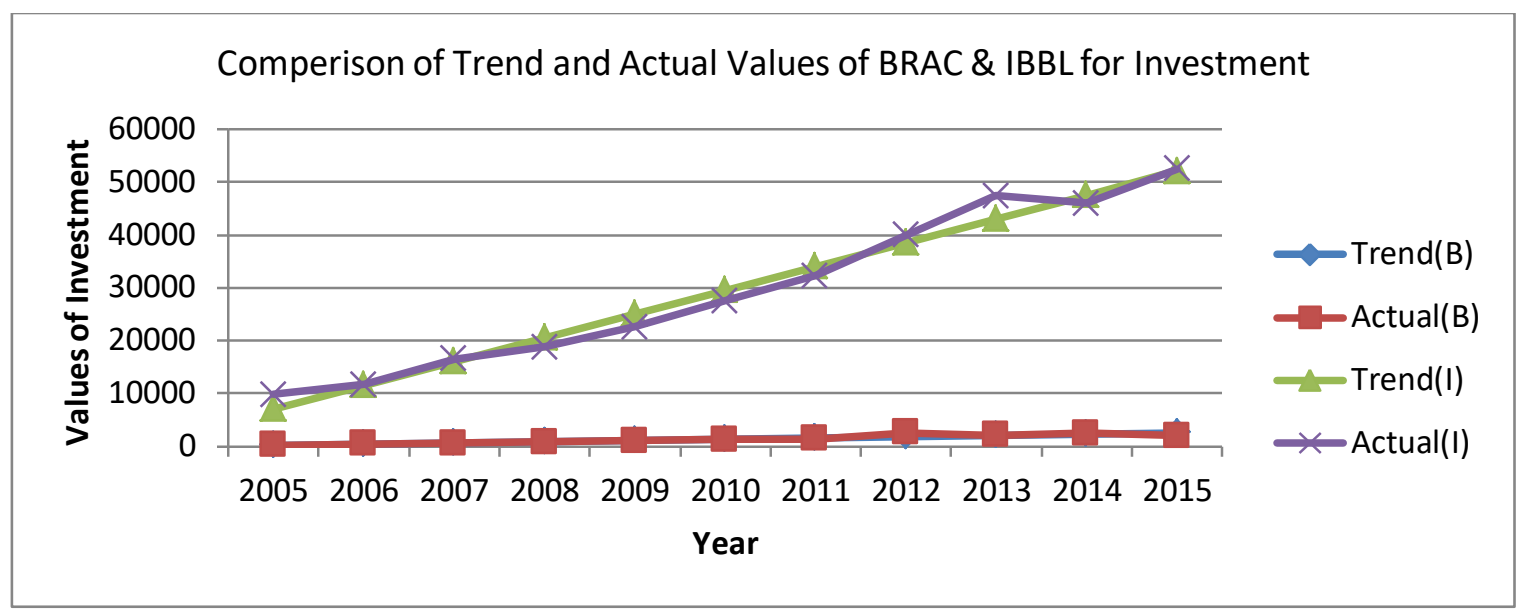

Source: Table No. 5.

Chart 3:

Table \# 5 and Chart \# 3 shows higher trend of IBBL than that of BBL regarding investment/loans and advances.

Table 6:

\begin{tabular}{|l|l|l|l|}
\hline \multicolumn{2}{|c|}{ Other Asset } \\
\hline YRAC & \multicolumn{1}{c|}{ IBBL } \\
\hline \multicolumn{1}{|c|}{ Tren.2+169.8X } & \multicolumn{1}{c|}{ Tctual } & \multicolumn{1}{c|}{ Trend } & \multicolumn{1}{c|}{ Actual } \\
\hline-85.8 & \multicolumn{1}{|c|}{ Act } & 220.33 & 243.73 \\
\hline 84 & 51.05 & 231.24 & 454.73 \\
\hline 253.8 & 118.97 & 242.15 & 100 \\
\hline 423.6 & 170.25 & 253.06 & 193.19 \\
\hline 593.4 & 253.69 & 263.97 & 87.4 \\
\hline 763.2 & 545.02 & 274.88 & 261.05 \\
\hline 933 & 675.74 & 285.79 & 310.99 \\
\hline 1102.8 & 1016.08 & 296.7 & 297.5 \\
\hline 1272.6 & 1318.67 & 307.61 & 447.18 \\
\hline 1442.4 & 1244.76 & 318.52 & 375.15 \\
\hline 1612.2 & 1419.2 & 329.43 & 252.72 \\
\hline
\end{tabular}

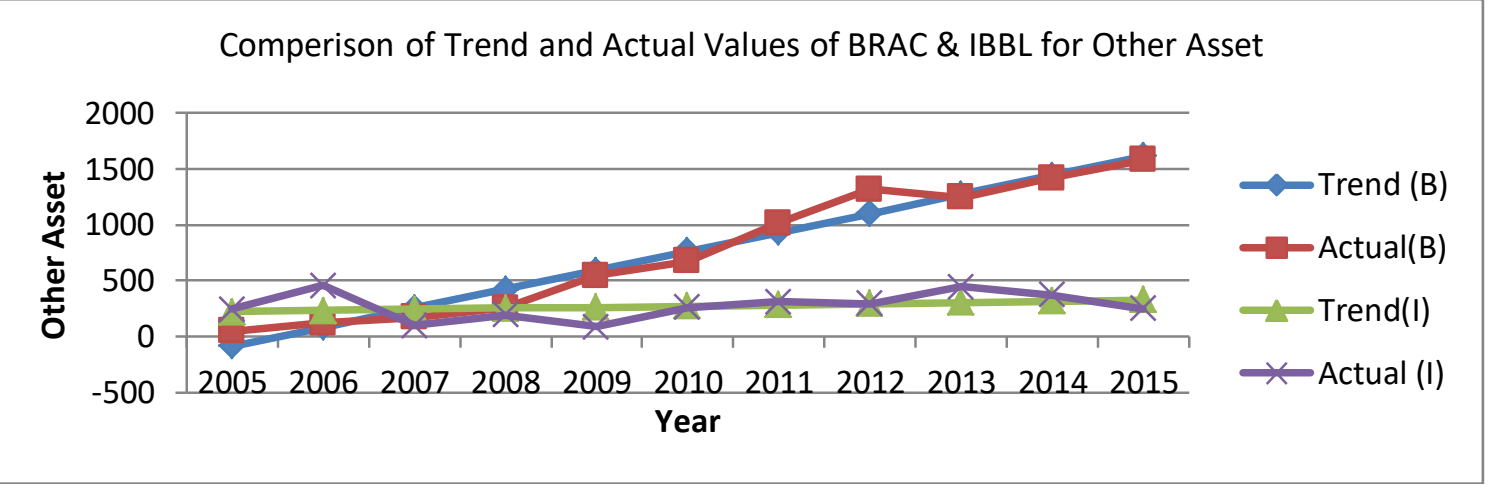

Source: Table No. 6.

Chart 4:

Table \# 6 and Chart \# 4 shows higher trend of IBBL than that of BBL regarding other assets. 
Table 7:

\begin{tabular}{|l|l|l|l|}
\hline \multicolumn{2}{|c|}{ Fixed Asset } \\
\hline \multicolumn{2}{|c|}{ BRAC } & \multicolumn{1}{c|}{ TBBL } \\
\hline \multicolumn{1}{|c|}{ Tr77.83+28.52X } & & \multicolumn{1}{c|}{ Trend } & \multicolumn{1}{c|}{ Actual } \\
\hline 35.23 & \multicolumn{1}{|c|}{ Actual } & 120.07 & 306.8 \\
\hline 63.75 & 15.64 & 273.98 & 372.47 \\
\hline 92.27 & 38.94 & 427.89 & 398.72 \\
\hline 120.79 & 94.29 & 581.8 & 440.72 \\
\hline 149.31 & 147.2 & 735.71 & 651.24 \\
\hline 177.83 & 163.8 & 889.62 & 674.84 \\
\hline 206.35 & 174.89 & 1043.53 & 710.02 \\
\hline 234.87 & 234.92 & 1197.44 & 1480.82 \\
\hline 263.39 & 259.15 & 1351.35 & 1573.28 \\
\hline 291.91 & 244.33 & 1505.26 & 1593.04 \\
\hline 320.43 & 289.3 & 1659.17 & 1583.85 \\
\hline
\end{tabular}

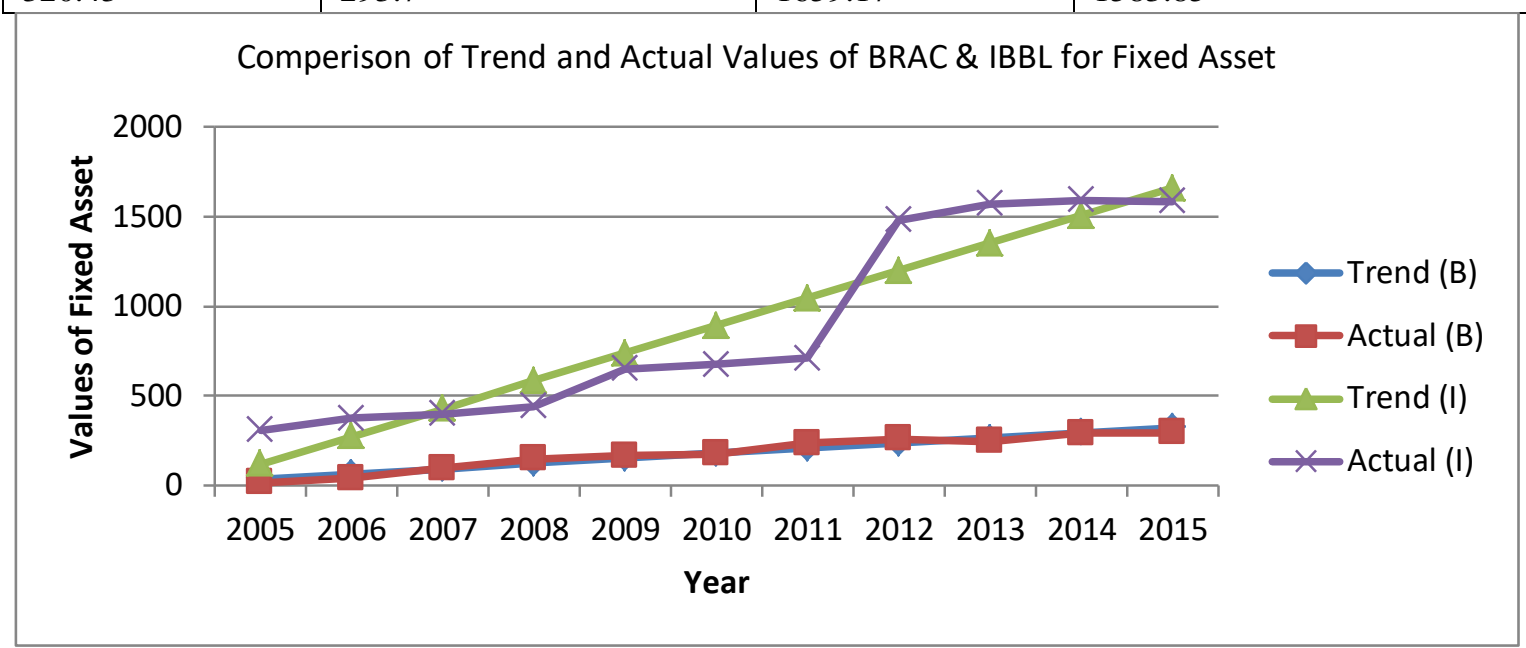

Source: Table No. 7.

Chart 5:

Table \# 7 and Chart \# 5 shows higher trend of IBBL than that of BBL regarding fixed assets.

Table 8:

\begin{tabular}{|l|l|l|l|}
\hline \multicolumn{2}{|c|}{ BRAC } & \multicolumn{2}{c|}{ IBBL } \\
\hline \multicolumn{2}{|c|}{ Y=1363.5+374.12X } & \multicolumn{1}{c|}{ Actual } & \multicolumn{2}{c|}{ Trend } & Actual \\
\hline \multicolumn{1}{|c|}{ Trend } & 101.15 & 1861.19 & 1842.14 \\
\hline-507.1 & 217.24 & 2207.24 & 2351.89 \\
\hline-132.98 & 311.46 & 2553.29 & 1707.64 \\
\hline 241.14 & 431.59 & 2899.34 & 3133.03 \\
\hline 615.26 & 661.9 & 3245.39 & 3748.57 \\
\hline 989.38 & 985.29 & 3591.44 & 3905.34 \\
\hline 1363.5 & 1197.86 & 3937.49 & 4063.18 \\
\hline 1737.62 & 1358.07 & 4283.54 & 4177.4 \\
\hline 2111.74 & & & \\
\hline
\end{tabular}




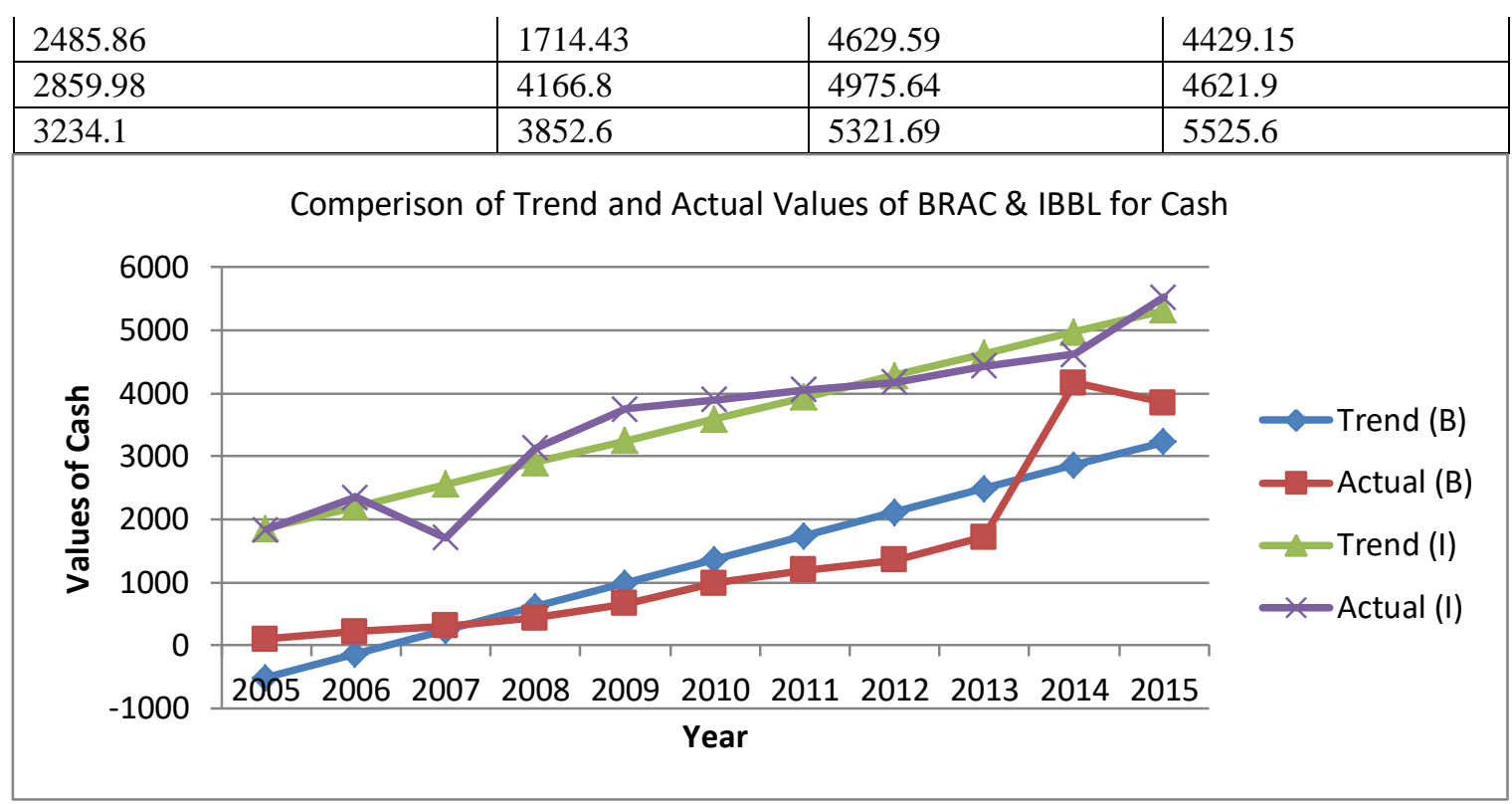

Chart 6:

Source: Table No. 8.

Table \# 8 and Chart \# 6 shows higher trend of IBBL than that of BBL regarding cash.

\section{Problems of IBBL}

\section{1) Absence of Suitable Islamic Money Market}

In Bangladesh, in the absence of a suitable Islamic money market, the Islamic banks cannot invest their temporary excess liquidity to earn any income rather it remains idle. Because all the Government treasury bills, approved securities and Bangladesh Bank's bonds are interest bearing. Naturally, the Islamic banks cannot invest the permissible part of their Security Liquidity Reserve and liquid surplus in those securities. On the other hand, that money is not used in call money market due to dealing in money, which is not Halal (approved). As a result, they deposit their whole reserve in cash with Bangladesh Bank. Similarly, the liquid surplus also remains un-invested. On the contrary, the conventional banks of the country do not suffer from this sort of limitations. As such, the profitability of the Islamic banks in Bangladesh is adversely affected.

\section{2) Lack of Suitable Long-term Assets}

The lack of suitable long-term assets available to Islamic banks is mirrored by lack of short term tradable financial instruments. At present, there is no equivalent of an inter-bank market in Bangladesh where banks could place, say, overnight funds, or where they could borrow to mitigate temporary liquidity crisis. But there is ample scope to do so by the conventional banks. Obviously, these factors are the distinct disadvantage for IBBL compared to its conventional counterpart.

\section{3) Shortage of Supportive and Link Institutions}

Any organization, business or system cannot succeed exclusively on its built-in elements. It is to depend on a number of link institutions. For identifying suitable projects, Islamic banking can profitably draw the services of economists, lawyers, insurance companies, management consultants, auditors and so on. They also need research and training forums in order to 
prompting entrepreneurship amongst their clients. Such type of liaison zone for Islamic banking is yet to be developed in Bangladesh.

\section{4) Lack of Strong Relationship with Foreign Banks}

Another important issue facing IBBL is how to enhance their relationships with foreign banks, and more generally, how to conduct international operations smoothly. This is, of course, an issue closely related to the creation of financial instruments, which would be simultaneously consistent with Islamic principles and acceptable to interest-based banks, including foreign banks.

\section{5) Lack of Long-term Financing Instruments}

Islamic Banks stick very closely to the pricing policies of the government. They cannot benefit from hidden costs and inputs, which elevate the level of prices by certain entrepreneurs without any justification. On the other hand, Islamic banks as financial institutions are even more directly affected by the failure of the projects they finance. This is because the built in security for getting back their funds, together with their profits, is in the success of the project. On the basis of Islamic Shariah, it is not lawful to obtain security from the partner against dishonesty or negligence, both of which are very difficult if not impossible to prove.

\section{Prospects and Recommendations}

On the basis of observation it can be said that the prospect of Islamic banking is very bright. Those are stated below:

1) Muslim people everywhere want Islamic banking. In Bangladesh, to give an example, $4 / 5$ conventional banks have opened separate Islamic branches recently. Five hundred applications are pending with Islamic Bank Bangladesh Ltd. for opening of new branches. IBBL has already 132 branches in the country.

2) The position may not be same in all countries. But if Islamic Banking succeeds in any country, the position will be same in every Muslim country. This means, that first Islamic bank in any country should be well managed and successful so that people have faith in this system. Established Islamic Banks should co-operate by lending competent officials in setting up new Islamic Banks.

3) The problems mentioned in the preceding pages are not insurmountable. Most of them can be solved with more research and dedicated efforts. IDB, OIC Fiqh Academy, International Islamic banking organizations and individual Islamic banks should put more resources in research in Islamic banking, Finance and Economic issues.

4) Cooperation of Central Banks and the Governments will be needed in some areas. It is hopeful that that Islamic banking will expand more and more in the entire world.

\section{Problems of BBL}

1) There are insufficient service stations for withdrawing and depositing money in the branch offices and for that reason often long queues are made thus increase the waiting time for the customers and eventually results in customer dissatisfaction.

2) All the money available in the bank are not always well utilized sometimes they remain as idle money.

3) A serious problem is occurring for the last few months that the ATM booths often becomes unusable mostly because of problems in ATM machines 
4) Often this is found that there is no money in the ATM machines but customers are waiting for withdrawing money.

5) They signify on their internet banking system but this has lots of problems and thus this is not convenient for the customers to use.

6) Employees in BRAC Bank get lower salary for which they sometimes lose the motivation.

7) Except few branch offices most of the branch offices have insufficient space.

8) Although the number of BRAC Bank booth is increasing but that is not adequate in comparison of its major competitors.

9) The information given about the Bank's features and many other things in the website is backdated.

\section{Recommendations}

1) In the branches of BBL there should be more number of service stations for withdrawing and depositing money so that it reduces the customer waiting time.

2) There should be more efficient capital management and investment analysts appointed so that idle money does not remain in the bank.

3) They should frequently keep their conscious observation to monitor that the ATM machines in all the booths are usable and adequate cash is there.

4) They should increase their ATM booths substantially in order to compete with its competitors.

5) They should update the information in the website in a regular basis.

6) BBL should increase the space in the branch offices as their client size is increasing day by day and also introduce new branches in various places of the country for expansion.

7) The managers should be sent to different training programs on a regular basis to improve their knowledge base which would help them to improve their efficiency.

8) Employees of BRAC Bank should be provided a better salary package in order to keep them otherwise they may switch to another job for higher salary.

9) Management should be more decentralized to provide faster services to the clients.

10) In order to remain as the market leading company they should emphasize much on retain the existing customer base and also should try to attract new customers.

11) In the loan approval procedure the evaluation of creditworthiness of the clients should be more authoritarian in order to reduce the chance of defaulter.

12) SME loan of BRAC Bank has already gained popularity to the businesspeople but there is an objection about the interest rate where the banks should be more aware and also try to decrease the interest rate. Because of higher rate of interest defaulter rate may increase which would ultimately affect the profitability of the bank.

\section{Conclusion}

BRAC Bank Limited and Islami Bank Bangladesh Limited are the two dominating banks in Bangladesh. But IBBL shows the better position in the five influential factors than those of BBL. But in the two banks there are some problems and prospects. If the Govt. and policy makers consider the recommendations the two banks will show better position in future. As BBL is 
newer than IBBL, so if BBL follows the recommendations its position will be enhanced day by day.

\section{References}

[1] Best Islamic Finance Institutions - 2008, Global Finance, 19 February 2009.

[2] BRAC Bank Limited, Annual Report 2005-2015.

[3] BRAC Bank Limited - Banglapedia, <en.banglapedia.org>

[4] BRAC Bank: 12 years of banking for financial inclusion, The Financial Express. 2012.

[5] BRAC Bank Limited: Knowing BRAC Bank, Company Profile, Corporate Vision, Mission \& Values". <www.bracbank.com.>

[6] Firoz, AM 21 February 2013, Islami Bank guided by economics, not politics, The Daily Sun.

[7] Islamic Financial Institutions Awards - 2009, Global Finance, 1 June 2009.

[8] Islami Bank Bangladesh Limited, Annual Report 2005-2015.

[9] Islami Bank Bangladesh Limited - Banglapedia, <en.banglapedia.org>

[10] Islam, MM and Alam, MA September 2013, Islami Bank Bangladesh Limited (PDF), BRAC EPL Stock Brokerage Ltd.

[11] Islami Bank Bangladesh Limited 27 September 2013, Bangladesh Institute of Bank Management.

[12] Mazid, MA 2012, Islami Bank Bangladesh Limited, In Islam, S and Jamal, AA, Banglapedia: National Encyclopedia of Bangladesh (Second ed.), Asiatic Society of Bangladesh.

[13] Rahman, MF 27 September 2013, Islamic banking on a roll, The Daily Star.

[14] https://en.wikipedia.org/wiki/BRAC_Bank

[15] https://en.wikipedia.org/wiki/Islami_Bank_Bangladesh_Ltd

[16] http://en.wikipedia.org/wiki/List_of_Banks_in_Bangladesh5

[17] http://www.BRACbank.com/php/include_submenu.php?pg=17

[18] http://www.termpaperslab.com/term-papers/117773.html8

[19] http://www.BRACbank.com/php/include_gen.php?pg=79

[20] http://www.federalreserve.gov/pubs/feds/1998/199832/199832pap.pdf

[21] http://www.shahfoundationbd.org/hannan/article10.html

[22] ttp://www.islamibankbd.com/docs/credit_rating_report.pdf

[23] ttps://www.islamicfinance.com/2015/07/al-rajhi-worlds-largest-islamic-bank

[24] http://www.islamibankbd.com/abtIBBL/abtIBBLCorpInfo.php

[25] https://www.islamibankbd.com/news.php?ID=103

*Corresponding author.

E-mail address: drabusina1970@ gmail.com 